\title{
ACE inhibitor use and severe angioedema
}

\author{
A Murray, J Crowther
}

The prescribing of angiotensin-converting enzyme (ACE) inhibitors in the management of hypertension and cardiac failure has increased greatly since their introduction in the 1980s. Generally, these drugs are considered safe, ${ }^{12}$ but they are known to precipitate angioedema as a side-effect, with an incidence of $0.1-0.2 \% .^{23}$ Angioedema is a non-pitting, erythematous oedema in the skin and subcutaneous tissues, which is well-defined and results in rapid, and often profound, soft tissue swelling which may be life-threatening, as the head and neck region is almost always affected. ${ }^{24}$ The numbers of reported cases of this association are increasing as usage of this group of drugs increases and it is now the most frequently identified cause in patients admitted with angioedema. $^{2-10}$

\section{Case reports}

Case 1

A 73-year-old hypertensive woman presented to Accident and Emergency (A\&E) with left-sided tongue swelling. She had had many episodes of angioedema over the previous 3 years, once requiring admission, and carried her own injectable adrenaline, though the reason for her angioedema had not been identified. She had been taking lisinopril $2.5 \mathrm{mg}$ for 3.5 years. She was admitted and given intravenous chlorpheniramine $10 \mathrm{mg}$ and hydrocortisone $200 \mathrm{mg}$. Her airway was satisfactory on fibre-optic examination. Over the next 2 hours she became stridulous. Repeat examination showed the base of her tongue and supraglottis to be swollen. Arrangements were made for her airway to be secured and repeat intravenous chlorpheniramine $10 \mathrm{mg}$, hydrocortisone $200 \mathrm{mg}$, and intramuscular adrenaline $1 \mathrm{mg}$ were administered. Within 20 minutes the patient's condition had dramatically improved and intubation/tracheostomy was averted. A further fibre-optic examination revealed much less oedema. Medical treatment was continued over the next 48 hours. The patient had been previously assessed for hereditary angioedema and had normal levels of $\mathrm{C} 1$ esterase inhibitor and complement. Her ACE inhibitor was stopped and she has had no further episodes of angioedema in 6 months.

\section{Case 2}

A 72-year-old woman with acute angioedema, also of her tongue and supraglottis, was sent by ambulance from her general practitioner to A\&E. Intravenous hydrocortisone $200 \mathrm{mg}$ and chlorpheniramine $10 \mathrm{mg}$ were administered, with intramuscular adrenaline $1 \mathrm{mg}$, and arrangements for tracheostomy were made, as no clear airway could be identified on fibreoptic examination. This was performed under local anaesthetic. Medical treatment was continued for 48 hours. The patient had been taking enalapril for 6 months and this was discontinued. She has had no further episodes of angioedema, after 6 months. Twice prior to admission the patient had been aware of her tongue being swollen, but had not sought advice. C1 esterase inhibitor levels were normal.

\section{Case 3}

A 71-year-old man was admitted to the Ear, Nose \& Throat ward with swelling of the floor of his mouth. He was taking trandolopril $4 \mathrm{mg}$ (an ACE inhibitor) as part of a clinical study in essential hypertension, and had been for the previous two years. A fibre-optic examination revealed no airway involvement. He had experienced minor episodes of angioedema over the preceding 8 months, including one admission to hospital. His $\mathrm{C} 1$ esterase inhibitor levels were normal. The ACE inhibitor was stopped. Due to worsening cardiac function, though, the man was recommenced on ACE inhibitors by a cardiologist (ramipril $2.5 \mathrm{mg}$ ). He has reported to the dermatology clinic that he has had a recurrence of his angioedema. We have since recommended that an alternative to an ACE inhibitor is used.

\section{Discussion}

Angioedema in ACE inhibitor users is a rare complication, although it is acknowledged in the Summaries of product characteristics of ACE inhibitors. The symptoms are frequently mild and self-limiting ${ }^{2-4}$ and the episodes often occur upon the commencement of treatment, although delays of months and even years have been reported. ${ }^{56}$

The mechanism for ACE inhibitors to produce angioedema is not clear but is probably through a tissue accumulation of bradykinin which is a potent vasodilator, as $\mathrm{ACE}$ is a bradykinin degrading (kininase) enzyme and the drugs inhibit this action. ${ }^{8}$ It is also clear that different ACE inhibitors have slightly different structures, and possibly differing levels of side-effects. For instance, captopril induces tissue-specific auto-antibodies much more frequently than enalapril, though the significance of this is uncertain. ${ }^{2}$ Present information is not adequate to identify clearly whether or not the true incidences of angioedema differ, ${ }^{39}$ and given the small percentages, a randomised controlled trial to answer 
this question would be difficult. It is obviously important, though, to notify the Committee on Safety of Medicines, of any possible drug reactions, even recognised ones, as was done with our patients, to allow possible patterns of sideeffects to be assessed.

The differential diagnoses of angioedema includes upper respiratory, or dental, infections, epiglottitis, asthma or anaphylaxis but the critical history of ACE inhibitor use must be elicited. If this is missed, and ACE inhibitor use continues, further episodes of angioedema may occur ${ }^{7}$ which may be life-threatening, as happened in two of our patients. A further critical point in the history is to ensure that patients previously suffering from idiopathic angioedema, are not commenced on ACE inhibitors, as this has clearly been shown to worsen the condition. ${ }^{10}$

Angioedema secondary to ACE inhibitors is not an allergic reaction and so management aimed solely at modifying the allergic response will not always be effective. Neither is there an abnormality of the complement system, as in hereditary angioedema, and $\mathrm{Cl}$ esterase inhibitor and $\mathrm{C} 4$ fraction levels can be measured to exclude this, where there is any doubt.

Treatment requires that the airway is secured and subcutaneous or intramuscular adrenaline given. The ACE inhibitor is stopped. Steroids

1 Inman WHW, Rawson NSB, Wilton LV, Pearce GL, Speirs CJ . Postmarketing surveillance of enalapril.1 Results of prescription-event monitoring. BMf 1988;297:826-9

2 Israili $\mathrm{ZH}$, Hall WD. Cough and angioneurotic edema associated with angiotensin-converting enzyme inhibitor therapy: a review of the literature and pathophysiology. Ann Intern Med 1992;117:234-42.

3 Slater EE, Merrill DD, Guess HA, et al. Clinical profile of angioedemaassociated with angiotensin converting enzyme angioedemaassociated with angiotensir

4 Megerian CA, Arnold JE, Berger M. Angioedema: 5 years' 4 Megerian CA, Arnold JE, Berger M. Angioedema: 5 years' experience, with a review of the disorder's
treatment. Laryngoscope 1992;102:256-60.

5 Forslund T, Tolano H, Weckstrom G, Stenborg M, Jarvinen $\mathrm{S}$. Angio-oedema induced by enalapril (Review). $\widetilde{\mathcal{J}}$ Intern Med 1995;238:179-81.

\section{Learning points}

- in patients admitted to hospital with angioedema, ACE inhibitor usage is the most frequently identified cause

- it should therefore be the first diagnosis considered by any clinician seeing a patient with angioedema

- angioedema almost always affects the head and neck and therefore the airway is at risk

- angioedema is not an allergic reaction and can occur many months after starting an ACE inhibitor

- patients with idiopathic angioedema should not receive $\mathrm{ACE}$ inhibitors, as their condition can worsen

have been used to modify the reaction and intravenous fluids and oxygen may also be needed.

In spite of the increasing body of literature available on this subject, doctors dealing with this emergency condition still appear to be unfamiliar with its features. The failure to change these patients' medication may be exposing them to significant risk.

Keywords: angioedema; angiotensin-converting enzyme inhibitor; airway obstruction

6 Jain M, Armstrong L, Hall J. Predisposition to and late onset of upper airway obstruction following angiotensinconverting enzyme inhibitor therapy (Review). Chest 1992; 102:871-4.

7 Finley CJ, Silverman MA, Nunez AE. Angiotensinconverting enzyme inhibitor-induced angioedema: still unrecognized. Am $₹$ Emerg Med 1992;10:550-2.

8 Jett JK. Captopril angioedema: first report. Ann Emerg Med 1984;13:489-90.

9 Hedner T, Samuelsson O, Lunde H, Lindholm L, Andren $\mathrm{L}$, Wiholm B. Angio-oedema in relation to treatment with angiotensin converting enzyme inhibitors. $B M \Im 1992 ; 304$ $941-6$

10 Orfan N, Patterson R, Dykewicz MS. Severe angioedema related to ACE inhibitors in patients with a history of idiopathic angioedema. $\mathcal{F A M A} 1990 ; 264: 1287-9$. 